\title{
Phylogenetic Relationships and Genetic Diversity in Collected Resources of Carthamus tinctorius by Random Amplified Polymorphic DNA Markers
}

\author{
Jung Sook Sung, Gyu Taek Cho, Gi An Lee, Hyung-Jin Baek and Man Kyu Huh* \\ National Academy of Agricultural Science, RDA, Suwon 441-100, Korea \\ ${ }^{1}$ Department of Molecular Biology, Dongeui University, Busan 614714, Korea
}

Received September 19, 2010 /Accepted November 19, 2010

\begin{abstract}
Carthamus tinctorius L. (Compositae) is an herb primarily distributed throughout in the world. The species is regarded as ecologically important in the world. Safflower was used for medicines, as well as making red (carthamin) and yellow dyes. We have used the RAPD technique to investigate the phylogenetic relationships and genetic diversity of $C$. tinctorius. We obtained 123 bands from all the 26 cultivars. The average number of bands was 9.5 per primer. The genetic diversity of safflower is found among cultivars and there is a high among-cultivar differentiation. The OPC18-01 band is the specific marker for Syria cultivar, whereas no products were detected in individuals from other country cultivars. We found seven phenetic bands for determining the specific marker of cultivars with SCAR markers. Though the number of individuals sampled for analysis was small and probably not fully representative of the total available diversity in C. tinctorius, this study demonstrates that the regions (Morocco, Syria, and Turkey) of the Mediterranean Sea were more variable than other regions with the exception of India. In this result, although only simple result of RAPD is difficult to assert the center of species diversity of $C$. tinctorius, the regions of the Mediterranean Sea may be the most probable candidate for the origin of safflower. India was also the candidate of the center or secondary center of species diversity of $C$. tinctorius. RAPD markers were effective in classifying cultivar levels of safflower.
\end{abstract}

Key words : Carthamus tinctorius, RAPD, safflower, genetic diversity

\section{Introduction}

Safflower (Carthamus tinctorius L.) is a highly branched, herbaceous, thistle-like annual, usually with many long sharps pines on the leaves [2]. Plants are 30 to $150 \mathrm{~cm}$ tall with globular flower heads (capitula) and commonly, brilliant yellow, orange or red flowers which bloom in July. Each branch will usually have from one to five flower heads containing 15 to 20 seeds per head [4].

Safflower is one of humanity's oldest crops. Chemical analysis of ancient Egyptian textiles dated to the Twelfth dynasty identified dyes made from safflower, and garlands made from safflower were found in the tomb of the pharaoh Tutankhamen. Chadwick [2] reported that the Greek name for safflower occurred many times in Linear B tablets, distinguished into two kinds: a white safflower, which is measured, and red which is weighed. The explanation is that there are two parts of the plant which can be used; the pale seeds and the red florets [2].

*Corresponding author

Tel : +82-51-890-1521, Fax : +82-51-890-1529

E-mail : mkhuh@deu.ac.kr
Traditionally, safflower was used for medicines, making red (carthamin), and yellow dyes, especially before cheaper aniline dyes became available [19]. In colouring textiles, safflower's dried flowers are used as a cultivar textile dye. Cultivar dyes derived from plants are not widely used in industry but it is getting more important world because of naturality and fashion trends. The colourful matter in safflower is benzoquinone-based Carthamin, so it is one of the quinone type natural dyes. It is a direct dye (CI Natural Red 26) and soluble.

Safflower was also known as carthamine in the 19th century [4]. It is a minor crop today, with about 600,000 tons being produced commercially in more than sixty countries worldwide. India, United States, and Mexico are the leading producers, with Ethiopia, Kazakhstan, China, Argentina and Australia accounting for most of the remainder [9].

Studies to clarify the overall status of several countries of this species were not conducted. Thus, the aim of this paper was to determine the compositions of the components of $C$. tinctorius for the first time and to compare it with the composition of $C$. tinctorius from the other countries.

Throughout this century a large number of samples from 
landraces of cultivated plants and from related wild species have been collected, and these are now available to breeders aiming at enlarging the genetic basis of these plant materials [10]. However, emphasis has been put on the general under uses of this potentially useful diversity in breeding programs [12]. This situation is partly due to the lack of a systematic genetic evaluation of plant collections. Information on germplasm diversity and genetic relationships among plant materials is therefore essential for breeders.

DNA-based RAPD (random amplified polymorphic DNA) has the advantage of being and easy, allowing resolution of complex patterns of genetic variation while the DNA sequence information is not available [11]. Although RAPD has the disadvantage of low reproductivity of marker bands and dominant of band markers, it is a preferable approach for safflower. In this paper, we have used the RAPD technique to investigate the genetic diversity of $C$. tinctorius and provide baseline information for crop management. The results from RAPD analysis may cast a light on the issue of genetic differentiation of the safflower and the origin of this species.

\section{Materials and Methods}

\section{Plant materials and DNA extraction}

Wild seeds were collected from 149 cultivated populations (or accessions) of $C$. tinctorius of 26 countries including Korea (Table 1). All seeds of samples were obtained from National Agrobiodiversity Center, NAAS, PDA (Suwon, Gyeonggi Province, Korea) which plants were collected from 26 countries in the world. The 100 collected seeds per population or cultivar were sown in to outdoor plots with same environmental conditions. We classified into 26 cultivars because same lineages were found among them.

We randomly selected ten plants per cultivar for the analyses within and among populations. Genomic DNA was isolated from one unexpended leaf of one plant. DNA was extracted with the plant DNA Zol Kit (Life Technologies Inc.,

Table 1. Codes of countries and measurements of genetic variation for 26 countries of $C$ tinctorius

\begin{tabular}{|c|c|c|c|c|c|c|c|c|}
\hline Code & Country & $\mathrm{Np}$ & $P p$ & $A$ & $A_{\mathrm{E}}$ & $H$ & $I$ & Rank \\
\hline AFG & Afghanistan & 10 & 8.13 & 1.081 & 1.058 & 0.034 & 0.049 & \\
\hline ARM & Armenia & 11 & 8.94 & 1.089 & 1.063 & 0.037 & 0.054 & \\
\hline AUS & Australia & 11 & 8.94 & 1.089 & 1.063 & 0.037 & 0.054 & \\
\hline AZE & Azerbaijan & 8 & 6.50 & 1.065 & 1.046 & 0.027 & 0.039 & \\
\hline CAN & Canada & 6 & 4.88 & 1.049 & 1.035 & 0.020 & 0.030 & \\
\hline $\mathrm{CHN}$ & China & 5 & 4.07 & 1.041 & 1.029 & 0.017 & 0.025 & \\
\hline EGY & Egypt & 6 & 4.88 & 1.049 & 1.035 & 0.020 & 0.030 & \\
\hline ETH & Ethiopia & 12 & 9.76 & 1.098 & 1.069 & 0.040 & 0.059 & 7 \\
\hline HUN & Hungary & 10 & 8.13 & 1.081 & 1.058 & 0.034 & 0.049 & \\
\hline IND & India & 16 & 13.01 & 1.130 & 1.092 & 0.054 & 0.079 & 1 \\
\hline IRN & Iran & 12 & 9.76 & 1.098 & 1.069 & 0.040 & 0.059 & 7 \\
\hline KAZ & Kazakhstan & 14 & 11.38 & 1.114 & 1.081 & 0.047 & 0.069 & 5 \\
\hline KOR & Korea & 9 & 7.32 & 1.073 & 1.052 & 0.030 & 0.044 & \\
\hline MAR & Morocco & 16 & 13.01 & 1.130 & 1.092 & 0.054 & 0.079 & 1 \\
\hline MEX & Mexico & 4 & 3.25 & 1.033 & 1.023 & 0.014 & 0.020 & \\
\hline PAK & Pakistan & 14 & 11.38 & 1.114 & 1.081 & 0.047 & 0.069 & 5 \\
\hline RUS & Russia & 8 & 6.50 & 1.065 & 1.046 & 0.027 & 0.039 & \\
\hline SDN & Sudan & 6 & 4.88 & 1.049 & 1.035 & 0.020 & 0.030 & \\
\hline SYR & Syria & 16 & 13.0 & 1.130 & 1.092 & 0.054 & 0.079 & 1 \\
\hline TKM & Turkmenistan & 10 & 8.13 & 1.081 & 1.058 & 0.034 & 0.049 & \\
\hline THA & Thailand & 4 & 3.25 & 1.033 & 1.023 & 0.014 & 0.020 & \\
\hline TJK & Tadzhikistan & 9 & 7.32 & 1.073 & 1.052 & 0.030 & 0.044 & \\
\hline TUR & Turkey & 16 & 13.01 & 1.130 & 1.092 & 0.054 & 0.079 & 1 \\
\hline UKR & Ukraine & 6 & 4.88 & 1.049 & 1.035 & 0.020 & 0.030 & \\
\hline USA & USA & 12 & 9.8 & 1.098 & 1.069 & 0.040 & 0.059 & 7 \\
\hline UZB & Uzbekistan & 9 & 7.32 & 1.073 & 1.052 & 0.030 & 0.044 & \\
\hline Mean & & 10.0 & 8.1 & 1.081 & 1.057 & 0.034 & 0.049 & \\
\hline
\end{tabular}

Rank: The nine highest genetic diversities among 26 countries. 
Grand Island, New York, USA) according to the manufacturer's protocol. Extracted DNA was quantified using Bio-Rad (Bio-Rad Laboratories, Inc., Hercules, CA, USA) according to the manufacturer's instructions.

\section{RAPD analysis}

RAPD primers were obtained from Operon Technologies Inc. (USA). All the reactions were repeated twice and only reproducible bands were scored for analyses. 40 primers (OPC01-OPC20 and OPD01-OPD20) used for a preliminary RAPD analysis. All the reactions were repeated twice and only the reproducible primers were used for analyses. The 13 primers produced good amplification products in quality, reproducibility, and variability (Table 2).

Amplification reactions were performed in total $50 \mathrm{ul}$ mixed solution containing $2.5 \mu \mathrm{l}$ of the reaction buffer, 10 $\mathrm{mM}$ Tris- $\mathrm{HCl}, 1.25 \mathrm{mM}$ dNTP, $5.0 \mathrm{pM}$ primer, 2.5 units Taq DNA polymerase, and $25 \mathrm{ng}$ of genomic DNA. DNA was amplified on a Takara PCR Thermal Cycler DICE (TP600, Japan) using the following programme. Initial denaturation was carried out for $1 \mathrm{~min}$ at $94^{\circ} \mathrm{C}$, followed by 35 cycles of $50 \mathrm{sec}$ at $94^{\circ} \mathrm{C}, 30 \mathrm{sec}$ at $45^{\circ} \mathrm{C}, 2 \mathrm{~min}$ at $72^{\circ} \mathrm{C}$, and a final $10 \mathrm{~min}$ extension at $72^{\circ} \mathrm{C}$.

A 100 bp ladder DNA marker (Pharmacia) was used in the end of for the estimation of fragment size. The amplification products were separated by electrophoresis on $1.5 \%$ agarose gels, stained with ethidium bromide, and photographed under UV light using Alpha Image TM (Alpha Innotech Co., USA).

To convert the selected RAPD band to a SCAR (sequence characterized amplified region) marker, the bands excised, cloned and sequenced following the procedure outlined in Jung et al. [8]. The excised PCR band was sequenced and the SCAR marker sequences were designed by identifying the original $10 \mathrm{bp}$ sequence of the RAPD primer. The specific SCAR primer were used different individuals of same cultivars and 25 different bulk cultivars which were not shown the band. The $5.0 \mathrm{ul}$ of amplification products were primarily separated by electrophoresis on $2.0 \%$ agarose gels, stained with ethidium bromide, and quantified the yield of total DNA using Bio-Rad.

\section{Statistical analyses}

All RAPD bands were scored by eye and only unambiguously scored bands were used in the analyses. Because RAPDs are dominant markers, they were assumed that each band corresponded to a single character with two alleles, presence (1) and absence (0) of the band, respectively. Loci were named based on the primer and observed band size.

The following genetic parameters were calculated using a POPGENE computer program (ver. 1.31) developed by Yeh et al. [18]: allele frequencies, the percentage of polymorphic loci $\left(P_{\mathrm{p}}\right)$, mean numbers of alleles per locus $(A)$, effective number of alleles per locus $\left(A_{\mathrm{E}}\right)$, gene diversity $(H)$, and Shannon's index of phenotypic diversity [14].

Nei's gene diversity formulae $\left(H_{\mathrm{T}}, H_{\mathrm{TS}}\right.$, and $\left.G_{\mathrm{ST}}\right)$ were used to evaluate the distribution of genetic diversity within and among cultivars [14]. The indirect estimates of gene flow, $N_{m}$ (the number of migrants per generation), were based on $G_{\text {ST }}$ [17].

Nei's genetic identity was calculated for each pairwise

Table 2. Lists of decamer oligonucleotide utilized as primers, their sequences, and associated bands

\begin{tabular}{|c|c|c|c|c|}
\hline \multirow{2}{*}{ No. of primer } & \multirow{2}{*}{ Sequence $\left(5^{\prime}-3^{\prime}\right)$} & \multirow{2}{*}{ No. of bands } & \multicolumn{2}{|c|}{ Cultivar-specific bands } \\
\hline & & & Band & Cultivar \\
\hline OPC07 & GTCCCGACGA & 6 & & \\
\hline OPC11 & AAAGCTGCGG & 7 & & \\
\hline OPC14 & TGCGTGCTTG & 7 & & \\
\hline OPC18 & TGAGTGGGTG & 8 & OPC18-01 & SYR \\
\hline OPC19 & GTTGCCAGCC & 6 & & \\
\hline OPC20 & ACTTCGCCAC & 11 & OPC20-7, 11 & ETH \\
\hline OPD01 & ACCGCGAAGG & 12 & OPD01-12 & UZB \\
\hline OPD04 & TCTGGTGAGG & 10 & & \\
\hline OPD07 & TTGGCACGGG & 12 & OPD07-12 & IND \\
\hline OPD10 & GGTCTACACC & 10 & & \\
\hline OPD12 & CACCGTATCC & 13 & & \\
\hline OPD16 & AGGGCGTAAG & 12 & OPD16-04 & PAK \\
\hline OPD20 & ACCCGGTCAC & 9 & OPD20-08 & SYR \\
\hline Total & - & 123 & 7 & 5 \\
\hline
\end{tabular}


Table 3. Estimates of genetic diversity of $C$. tinctorius. Total genetic diversity $\left(H_{\mathrm{T}}\right)$, genetic diversity within cultivars $\left(H_{k}\right)$ proportion of total genetic diversity partitioned among cultivars $\left(G_{\mathrm{ST}}\right)$, and gene flow $\left(N_{m}\right)$

\begin{tabular}{ccccc}
\hline Primer & $H_{\Gamma}$ & $H_{s}$ & $G_{\text {ST }}$ & $N_{m}$ \\
\hline OPC07 & 0.266 & 0.029 & 0.765 & 0.043 \\
OPC11 & 0.268 & 0.001 & 0.807 & 0.036 \\
OPC14 & 0.316 & 0.030 & 0.905 & 0.059 \\
OPC18 & 0.361 & 0.042 & 0.907 & 0.058 \\
OPC19 & 0.155 & 0.019 & 0.448 & 0.038 \\
OPC20 & 0.240 & 0.044 & 0.726 & 0.200 \\
OPD01 & 0.189 & 0.015 & 0.784 & 0.030 \\
OPD04 & 0.257 & 0.024 & 0.732 & 0.042 \\
OPD07 & 0.229 & 0.028 & 0.678 & 0.044 \\
OPD10 & 0.232 & 0.030 & 0.619 & 0.052 \\
OPD12 & 0.169 & 0.015 & 0.650 & 0.137 \\
OPD16 & 0.280 & 0.061 & 0.671 & 0.236 \\
OPD20 & 0.264 & 0.085 & 0.607 & 0.214 \\
Total & 0.248 & 0.033 & 0.715 & 0.091 \\
\hline
\end{tabular}

combination of cultivars [14]. Homogeneity of variance among accessions was tested by Bartlett's statistics.

The Mantel test was examined the correlation between the matrix of genetic distance and spatial distance within a site.

A maximum parsimony tree (MP) was inferred using heuristic search, branch-swapping options and tree bisectionreconnection. Confidence values for individual branches were determined by a bootstrap analysis with 1000 repeated sampling of the data. In addition, a phenetic relationship was constructed by the neighborjoining (NJ) method [16] using the NEIGHBOR program in PHYLIP version 3.57 [5].

\section{Results}

We obtained 123 bands from all the cultivars (Table 2). The average number of bands was 9.5 per primer. Of all cultivars, $82.9 \%$ were polymorphic among all cultivars. In a simple percentage of polymorphic bands, the Mexico cultivar and Thailand cultivar exhibited the lowest variation $(3.3 \%)$. The India, Morocco, and Syria cultivars showed the highest (13.0\%) (Table 1). Mean number of alleles per locus (A) from 1.033 to 1.130 with a mean of 1.081 . The effective number of alleles per locus $\left(A_{\mathrm{E}}\right)$ ranged from1.023 to 1.092 . The phenotypic frequency of each band was calculated and used for estimating genetic diversity $(H)$ within cultivars. The safflower maintained a low level of genetic diversity for polymorphic primers. The total $H$ was 0.034 across cultivars. Shannon's index of phenotypic diversity $(I)$ of safflower ranged from 0.020 to 0.079 with a mean of 0.049 . The nine highest genetic diversities among 26 countries were India, Moroco, Syria, Turkey, Kazakhstan, Pakistan, Ethopia, Iran, and USA (Table 2).

Total genetic diversity values $\left(H_{\mathrm{I}}\right)$ and interlocus variation in the within-cultivar genetic diversity $\left(H_{\mathcal{S}}\right)$ were 0.248 and 0.033 , respectively (Table 3 ). On a per-locus basis, the proportion of total genetic variation due to differences among cultivars $\left(G_{S T}\right)$ was 0.715 . This indicated that about $71.5 \%$ of the total variation was among cultivars. These values indicate that most of the genetic diversity of safflower is found among cultivars and there is a high among-cultivar differentiation. The remaining genetic variation $(28.5 \%)$ was occurring within cultivars. The estimate of gene flow, based on $G_{\text {ST, }}$ was slightly low among cultivars of safflower $\left(N_{m}=0.091\right)$.

Values of genetic distance (D) were $<0.463$ (Table 4). Genetic identity values among pairs of cultivars ranged from 0.630 to 0.907 .

The Mantel test was used to test for correlations between the matrix of genetic diversity and spatial distance. Genetic diversity did not almost correlate with spatial distance in safflower cultivars.

The OPC18-01 band is the specific marker for the Syria cultivar, whereas no products were detected in individuals from other country cultivars (Fig. 1). The specific DNA fragment seemed to be useful to discriminate among cultivars and was used to develop the SCAR marker. Figure 2 gave rise to the yield of total DNA using Bio-Rad. We found many phenetic bands for determining the specific marker of cultivar with SCAR markers (Table 2). Seven bands (OPC18-01, 
Table 4. Genetic identity (above diagonal) and genetic distances (below diagonal) of 27 cultivars of Carthamus tinctorius (Compositae) based on RAPD

\begin{tabular}{|c|c|c|c|c|c|c|c|c|c|c|c|c|c|}
\hline Code & AFG & ARM & AUS & AZE & CAN & $\mathrm{CHN}$ & EGY & ETH & HUN & IND & IRN & KAZ & KOR \\
\hline$\overline{\mathrm{AFG}}$ & - & 0.832 & 0.853 & 0.853 & 0.765 & 0.771 & 0.770 & 0.830 & 0.671 & 0.777 & 0.792 & 0.765 & 0.750 \\
\hline ARM & 0.184 & - & 0.775 & 0.898 & 0.848 & 0.770 & 0.734 & 0.796 & 0.692 & 0.765 & 0.784 & 0.728 & 0.810 \\
\hline AUS & 0.159 & 0.254 & - & 0.775 & 0.784 & 0.795 & 0.732 & 0.819 & 0.699 & 0.781 & 0.767 & 0.788 & 0.724 \\
\hline AZE & 0.159 & 0.108 & 0.256 & - & 0.806 & 0.755 & 0.763 & 0.791 & 0.672 & 0.733 & 0.765 & 0.710 & 0.670 \\
\hline CAN & 0.244 & 0.165 & 0.244 & 0.216 & - & 0.818 & 0.735 & 0.758 & 0.737 & 0.835 & 0.778 & 0.829 & 0.709 \\
\hline $\mathrm{CHN}$ & 0.260 & 0.261 & 0.229 & 0.281 & 0.201 & - & 0.745 & 0.737 & 0.709 & 0.828 & 0.749 & 0.775 & 0.721 \\
\hline EGY & 0.261 & 0.309 & 0.312 & 0.311 & 0.308 & 0.295 & - & 0.793 & 0.632 & 0.797 & 0.834 & 0.808 & 0.663 \\
\hline ETH & 0.186 & 0.228 & 0.199 & 0.235 & 0.278 & 0.305 & 0.232 & - & 0.630 & 0.767 & 0.824 & 0.800 & 0.683 \\
\hline HUN & 0.399 & 0.369 & 0.359 & 0.397 & 0.306 & 0.343 & 0.460 & 0.463 & - & 0.663 & 0.692 & 0.674 & 0.723 \\
\hline IND & 0.253 & 0.268 & 0.248 & 0.311 & 0.180 & 0.189 & 0.227 & 0.265 & 0.412 & - & 0.765 & 0.790 & 0.709 \\
\hline IRN & 0.234 & 0.244 & 0.266 & 0.268 & 0.251 & 0.289 & 0.182 & 0.193 & 0.368 & 0.268 & - & 0.809 & 0.651 \\
\hline KAZ & 0.268 & 0.317 & 0.238 & 0.342 & 0.188 & 0.255 & 0.214 & 0.223 & 0.395 & 0.236 & 0.213 & - & 0.707 \\
\hline KOR & 0.288 & 0.345 & 0.324 & 0.401 & 0.343 & 0.327 & 0.410 & 0.381 & 0.325 & 0.344 & 0.429 & 0.346 & - \\
\hline MAR & 0.328 & 0.220 & 0.284 & 0.309 & 0.193 & 0.292 & 0.408 & 0.260 & 0.399 & 0.237 & 0.337 & 0.262 & 0.357 \\
\hline MEX & 0.299 & 0.218 & 0.247 & 0.260 & 0.218 & 0.289 & 0.415 & 0.251 & 0.386 & 0.321 & 0.363 & 0.229 & 0.367 \\
\hline PAK & 0.259 & 0.210 & 0.221 & 0.274 & 0.231 & 0.253 & 0.273 & 0.240 & 0.341 & 0.246 & 0.251 & 0.276 & 0.386 \\
\hline RUS & 0.233 & 0.156 & 0.194 & 0.188 & 0.174 & 0.266 & 0.325 & 0.173 & 0.358 & 0.255 & 0.244 & 0.205 & 0.349 \\
\hline SDN & 0.231 & 0.154 & 0.254 & 0.218 & 0.177 & 0.290 & 0.361 & 0.217 & 0.406 & 0.253 & 0.258 & 0.242 & 0.357 \\
\hline SYR & 0.196 & 0.071 & 0.255 & 0.109 & 0.169 & 0.246 & 0.306 & 0.199 & 0.401 & 0.268 & 0.244 & 0.276 & 0.386 \\
\hline TKM & 0.261 & 0.217 & 0.232 & 0.260 & 0.207 & 0.269 & 0.285 & 0.293 & 0.379 & 0.189 & 0.305 & 0.278 & 0.351 \\
\hline THA & 0.222 & 0.240 & 0.225 & 0.306 & 0.210 & 0.191 & 0.231 & 0.275 & 0.380 & 0.179 & 0.261 & 0.278 & 0.373 \\
\hline TJK & 0.304 & 0.185 & 0.245 & 0.247 & 0.128 & 0.228 & 0.334 & 0.287 & 0.343 & 0.215 & 0.278 & 0.244 & 0.312 \\
\hline TUR & 0.266 & 0.216 & 0.224 & 0.299 & 0.206 & 0.289 & 0.321 & 0.230 & 0.401 & 0.240 & 0.272 & 0.256 & 0.357 \\
\hline UKR & 0.196 & 0.236 & 0.197 & 0.214 & 0.283 & 0.272 & 0.267 & 0.210 & 0.450 & 0.317 & 0.288 & 0.284 & 0.303 \\
\hline USA & 0.255 & 0.187 & 0.246 & 0.233 & 0.219 & 0.296 & 0.363 & 0.256 & 0.422 & 0.248 & 0.290 & 0.262 & 0.397 \\
\hline UZB & 0.168 & 0.218 & 0.142 & 0.181 & 0.282 & 0.282 & 0.271 & 0.162 & 0.445 & 0.253 & 0.267 & 0.277 & 0.313 \\
\hline Code & MAR & MEX & PAK & RUS & SDN & SYR & TKM & THA & TJK & TUR & UKR & USA & UZB \\
\hline AFG & 0.720 & 0.742 & 0.772 & 0.792 & 0.794 & 0.822 & 0.770 & 0.801 & 0.738 & 0.766 & 0.822 & 0.775 & 0.845 \\
\hline ARM & 0.805 & 0.804 & 0.810 & 0.856 & 0.858 & 0.931 & 0.805 & 0.7875 & 0.831 & 0.806 & 0.790 & 0.830 & 0.804 \\
\hline AUS & 0.753 & 0.781 & 0.802 & 0.824 & 0.776 & 0.775 & 0.793 & 0.798 & 0.783 & 0.800 & 0.821 & 0.782 & 0.868 \\
\hline AZE & 0.735 & 0.771 & 0.761 & 0.829 & 0.804 & 0.897 & 0.771 & 0.737 & 0.781 & 0.742 & 0.808 & 0.792 & 0.835 \\
\hline CAN & 0.825 & 0.804 & 0.794 & 0.840 & 0.838 & 0.845 & 0.813 & 0.810 & 0.880 & 0.815 & 0.754 & 0.803 & 0.755 \\
\hline $\mathrm{CHN}$ & 0.747 & 0.749 & 0.777 & 0.767 & 0.748 & 0.782 & 0.764 & 0.826 & 0.796 & 0.742 & 0.762 & 0.744 & 0.754 \\
\hline EGY & 0.665 & 0.660 & 0.761 & 0.722 & 0.697 & 0.736 & 0.752 & 0.794 & 0.716 & 0.756 & 0.766 & 0.695 & 0.763 \\
\hline ETH & 0.771 & 0.778 & 0.786 & 0.841 & 0.805 & 0.820 & 0.746 & 0.760 & 0.751 & 0.794 & 0.811 & 0.774 & 0.850 \\
\hline HUN & 0.671 & 0.680 & 0.711 & 0.699 & 0.666 & 0.670 & 0.684 & 0.684 & 0.709 & 0.670 & 0.638 & 0.656 & 0.641 \\
\hline IND & 0.789 & 0.726 & 0.782 & 0.775 & 0.776 & 0.765 & 0.828 & 0.836 & 0.807 & 0.786 & 0.729 & 0.781 & 0.776 \\
\hline IRN & 0.714 & 0.695 & 0.778 & 0.784 & 0.773 & 0.784 & 0.737 & 0.770 & 0.758 & 0.762 & 0.750 & 0.748 & 0.765 \\
\hline KAZ & 0.769 & 0.795 & 0.759 & 0.815 & 0.785 & 0.759 & 0.757 & 0.758 & 0.784 & 0.774 & 0.753 & 0.769 & 0.758 \\
\hline KOR & 0.700 & 0.693 & 0.680 & 0.706 & 0.700 & 0.680 & 0.704 & 0.689 & 0.732 & 0.700 & 0.739 & 0.672 & 0.732 \\
\hline MAR & - & 0.840 & 0.779 & 0.850 & 0.871 & 0.807 & 0.765 & 0.750 & 0.820 & 0.809 & 0.706 & 0.879 & 0.740 \\
\hline MEX & 0.174 & - & 0.769 & 0.881 & 0.818 & 0.788 & 0.757 & 0.724 & 0.801 & 0.792 & 0.746 & 0.810 & 0.759 \\
\hline PAK & 0.250 & 0.263 & - & 0.829 & 0.796 & 0.792 & 0.868 & 0.850 & 0.812 & 0.874 & 0.771 & 0.807 & 0.816 \\
\hline RUS & 0.162 & 0.127 & 0.188 & - & 0.871 & 0.871 & 0.816 & 0.811 & 0.836 & 0.820 & 0.805 & 0.869 & 0.831 \\
\hline SDN & 0.138 & 0.201 & 0.228 & 0.138 & - & 0.880 & 0.757 & 0.794 & 0.816 & 0.802 & 0.728 & 0.892 & 0.787 \\
\hline SYR & 0.215 & 0.239 & 0.234 & 0.138 & 0.128 & - & 0.793 & 0.777 & 0.794 & 0.805 & 0.792 & 0.849 & 0.815 \\
\hline TKM & 0.268 & 0.279 & 0.142 & 0.203 & 0.279 & 0.232 & - & 0.865 & 0.820 & 0.881 & 0.784 & 0.771 & 0.789 \\
\hline THA & 0.287 & 0.323 & 0.163 & 0.209 & 0.231 & 0.253 & 0.145 & - & 0.839 & 0.837 & 0.742 & 0.765 & 0.774 \\
\hline TJK & 0.198 & 0.222 & 0.208 & 0.179 & 0.203 & 0.231 & 0.198 & 0.176 & - & 0.790 & 0.771 & 0.798 & 0.768 \\
\hline TUR & 0.212 & 0.234 & 0.134 & 0.199 & 0.220 & 0.217 & 0.127 & 0.178 & 0.236 & - & 0.730 & 0.783 & 0.769 \\
\hline UKR & 0.348 & 0.294 & 0.260 & 0.217 & 0.318 & 0.234 & 0.243 & 0.299 & 0.261 & 0.315 & - & 0.760 & 0.907 \\
\hline USA & 0.129 & 0.211 & 0.214 & 0.141 & 0.114 & 0.164 & 0.260 & 0.268 & 0.226 & 0.245 & 0.274 & - & 0.791 \\
\hline UZB & 0.301 & 0.275 & 0.204 & 0.185 & 0.240 & 0.205 & 0.238 & 0.256 & 0.264 & 0.262 & 0.098 & 0.234 & - \\
\hline
\end{tabular}


M AFG ARM AUS AZE CAN CHN EGY ETH HUN IND IRN KAZ KOR MAR MEX PAK RUS SDN SYR TKM THA TJK TUR UKR USA UZB

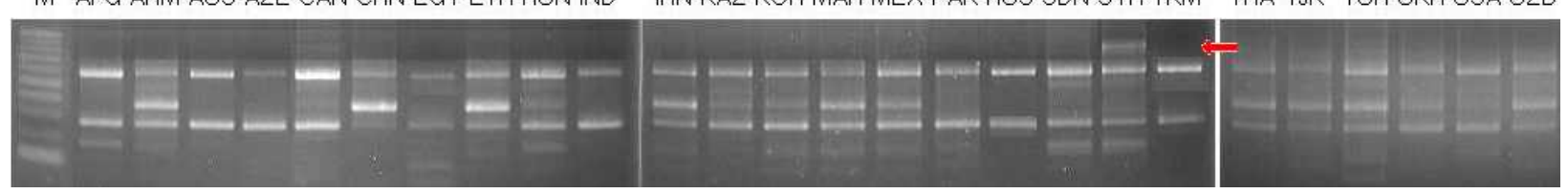

Fig. 1. The specific band of SYR (Syria) with the OPC18 primer. Abberations of AFG, ARM, AUS, and so on are the same as Table $1 . \mathrm{M}$ is the $100 \mathrm{bp}$ ladder DNA marker.
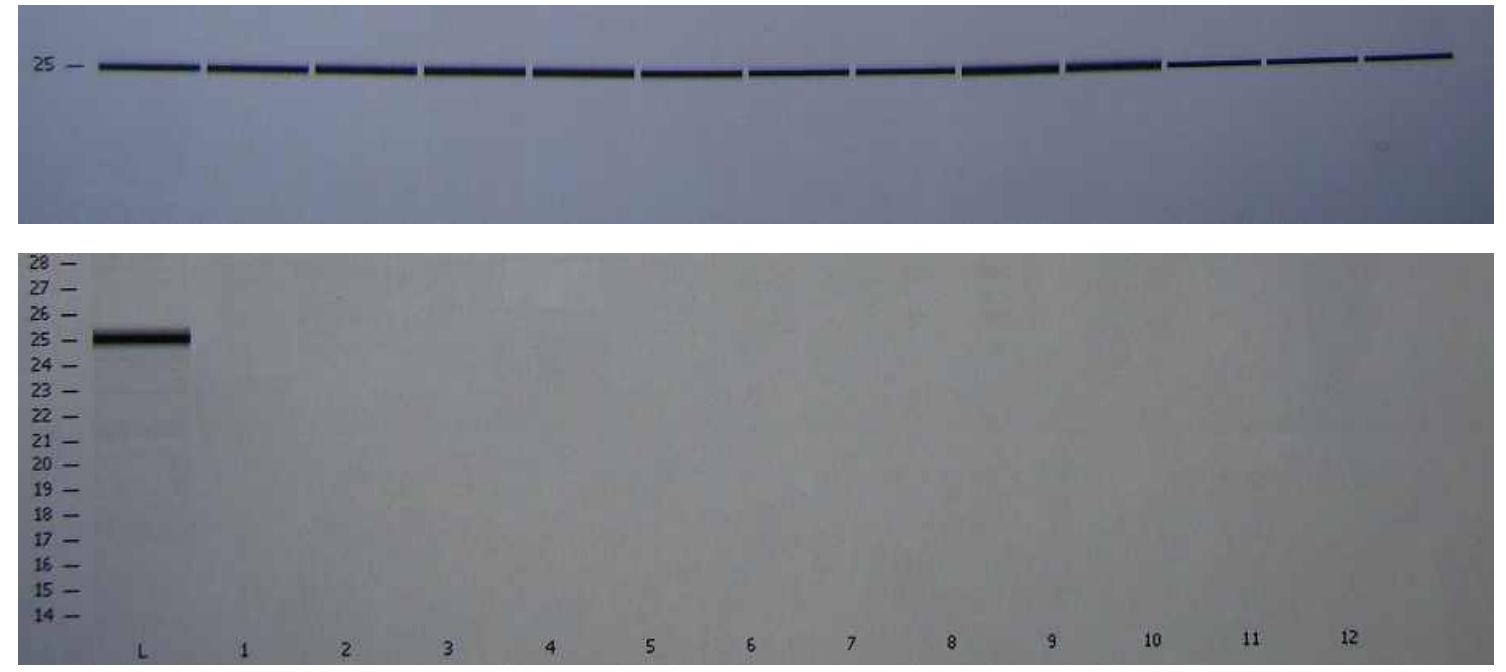

Fig. 2. The quantified specific band to 13 different Syria individuals (upper). and the specific band of Syria (L) is not amplified other country bulk samples (1-12) (below).

OPC20-07, 11, OPD01-12, OPD07-12, OPD16-04, and OPD20-08) are specific for one cultivar.

Clustering of accessions was performed based on the matrix of calculated distances using the NJ algorithm (Fig. 3). In dendrogram, many cultivars were well separated from each other. Thus, RAPD markers are effective in classifying cultivar levels of safflower though 26 countries could not distinguish each other perfectly on the basis of phenotypic traits. Although many cultivars were separated from each other, there were numerous discrepancies among the clades obtained here.

\section{Discussion}

We analyzed 26 countries of $C$. tinctorius with the internal transcribed spacer (ITS) region of nuclear ribosomal DNA using primers ITS1 and ITS4 [1]. However they were same sequences with 703 or $704 \mathrm{bp}$. Only one nucleotide was changed and one was inserted. Thus, we could not use the detailed information of differences of 26 countries within this species.
To better define the morphological traits in various countries, associations among 24 traits, were investigated by principal coordinate analysis (PCA) (Fig. 4). The locations of countries were defined by the two first principal coordinates, PC1 and PC2, which explained $32.7 \%$ and $16.8 \%$ of total variation in morphological traits. All the 26 countries, Australia and Russia were situated adjacent to one another though geographical distance is very remote. The Korean cultivar is isolated from cultivars of other countries.

This study demonstrates that RAPDs offer a suitable method for detection of genetic variability in safflower. The degree of polymorphism revealed in the three $C$. tinctorius cultivars by amplification with arbitrary primers is extensive. Partitioning of genetic variability indicates that, on average, $71.5 \%$ is distributed between, and $28.5 \%$ within, cultivars. These findings are not in agreement with the observation that out-breeding plants retain considerable variability and most variation is exhibited within cultivars [7]. Though the number of individuals sampled for analysis was small and probably not fully representatives of the total available diversity in $C$. tinctorius, our study demonstrates 


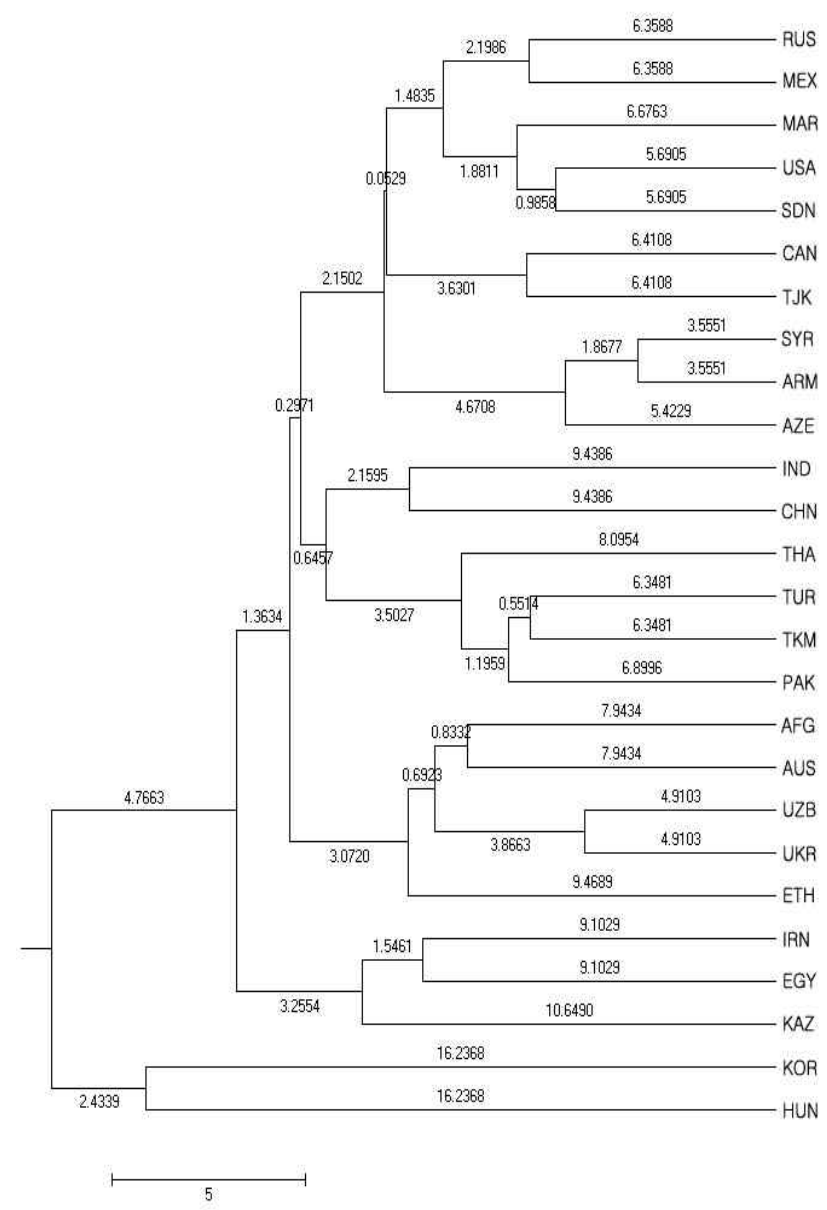

Fig. 3. A Phylogenetic tree for 26 countries based on RAPD analysis.

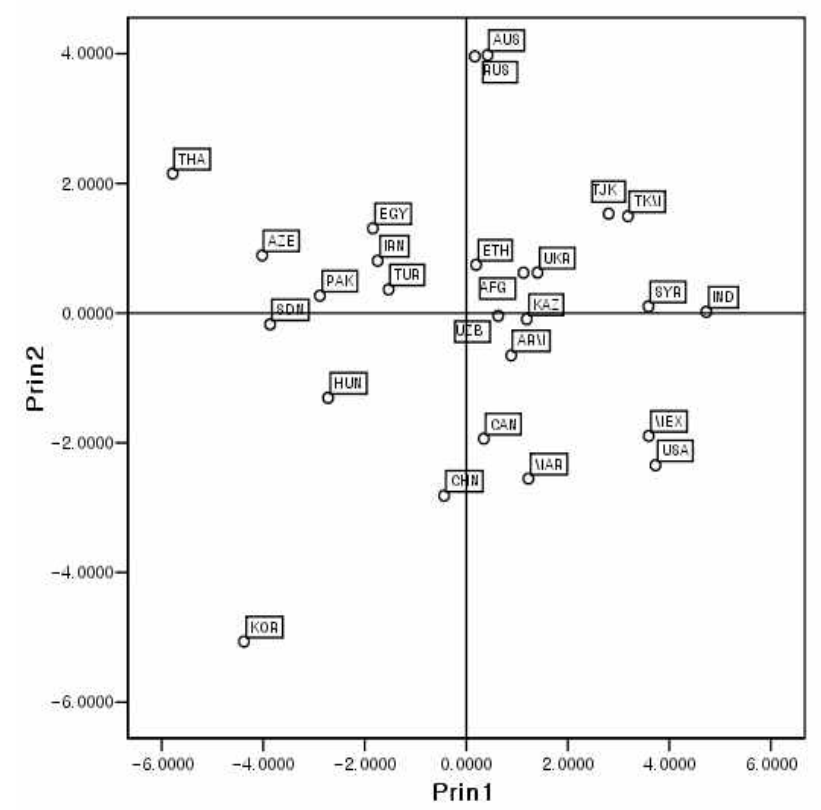

Fig. 4. Results of principal component analyses of 24 morphological data in $C$. tinctorius. that the regions (Morocco, Syria, and Turkey) of the Mediterranean Sea are more variable than other regions except India (Table 1). In this result, although only simple result of RAPD is difficult to assert the center of species diversity of $C$. tinctorius, the regions of the Mediterranean Sea may be the most probable candidate for the origin of safflower. India was also the candidate of the center or secondary center of species diversity of $C$. tinctorius.

If the RAPD analyses are reliable in their ability to detect variability among $C$. tinctorius cultivars, then this method can be used to study the diffusion routes of cultivated plants because variability among cultivates should reflect their phylogenetic relationship after domestication. This investigation of the diffusion routes of safflower by comparing RAPD markers among cultivars is based on several assumptions. The cultivars that were used in the analyses are more or less the same as those that diffused in the past or are the direct descendants of the plants that diffused. Diffusion took place stepwise without long distance migration.

If Korean safflower cultivars, for example, consist of mixture of those that diffused with Chinese and India accessions in ancient times and those that diffused recently, or some cultivars came directly from remote areas as a result of long distance migration, then some cultivars will have quite different positions in the phylogenetic tree (Fig. 3) to their geographical positions, and the phylogenetic relationship among Asian cultivars will be confusing as similar cases.

Although the amount variability detected with RAPD analysis is dependent upon the selection of appropriate primers and problems with reproducibility have plagued the use of this technique in the past, this method has the advantage of being inexpensive and simple to perform, and does not require a previous knowledge of the genome [6]. However, we were able to limit these problems in this study, as evidenced by the results of our duplicate analysis, by careful DNA preparation, strict adherence to amplification protocols and a rigorous interpretation of the results. We also found the results of RAPD to be faster and easier to interpret than ITS techniques studied, making it an ideal technique for use in the identification of $C$. tinctorius accessions or cultivars. Based on the results study, RAPD markers were the least polymorphic markers of those evaluated, and consequently had the least resolving power. 


\section{Acknowledgements}

This work was supported by PJ0066562010 Research on Collection and Introduction of Plant Genetic Diversity and PJ0075062010 Regeneration and Assessment of Horticultural Plants and Medicinal Plants Germplasm.

\section{References}

1. Baldwin, B. G. 1993. Molecular phylogenetics of Calcydenia (Compositae) based on ITS sequences of nuclear ribosomal DNA: chromosomal and morphological evolution reexamined. Am J. Bot. 80, 222-238.

2. Chadwick, J. 1976. The Mycenaean World pp. 120, Cambridge University Press, Cambridge.

3. De Candolle, A. 1885. Origin of Cultivated Plants. Retrieved on 2007-09-25. pp.164, D. Appleton \& Co, New York.

4. DeClerck, F. A. J., M. G. Barrour, and J. O. Sawyer. 2006. Species richness and stand stability in conifer forests of the Sierra Nevada. Ecology 87, 2787-2799.

5. Felsenstein, J. 1993. PHYLIP (Phylogeny Inference Package) Version 3.5s. Distributed by the Author. Department of Genetics, Univ. of Washington, Seattle.

6. Gallego, F. J., M. A. Perez, Y. Nunez, and P. Hidalgo. 2005. Comparison of RAPDs, AFLPs and SSR markers for the genetic analysis of yeast strains of Saccharomy cescerevisiae. Food Microbiology 22, 561-568.

7. Hamrick, J. L. and M. J. W. Godt. 1989. Allozyme Diversity in Plant Species, pp. 304-319, In Brown, A. H. D., M. T. Clegg, A. L. Kahler, and B. S. Weir (eds.), Plant population genetics, breeding and genetic resources, Sinauer Associates, Sunderland, MA.

8. Jung, G., P. W. Skroch, J. Nienhuis, D. P. Coyne, E. Arnaud-Santana, H. M. Ariyarathne, and J. M. Marita. 1999. Confirmation of QTL associated with common bacterial blight resistance in four different genetic backgrounds in common bean. Crop Sci. 39, 1448-1455.

9. Knowles, P. F. 1989. Safflower, pp. 363-374, In Röobbelen, G., R. K. Downey, and A. Ashri (eds.), Oil crops of the world, McGraw-Hill, New York.

10. Lubberstedt, T., A. E. Melchinger, C. Duble, M. Vuylsteke, and M. Kuiper. 2000. Relationships among early Europe maize inbreds: IV. Genetic diversity revealed with AFLP markers and comparison with RFLP, RAPD, and pedigree data. Crop Sci. 40, 783-791.

11. Lynch, M. and B. G. Milligan. 1994. Analysis of population genetic structure with RAPD markers. Mol. Ecol. 3, 91-99.

12. Marshall, D. R. 1989. Limitations to the use of germplasm collections, pp. 105-120, In Brown, A. H. D., D. R. Marshall, and J. T. Williams (eds.), The use of plant genetic resources. Cambridge University Press, Cambridge.

13. Nei, M. 1973. Analysis of gene diversity in subdivided populations. Proc. Natl. Acad Sci. USA. 70I, 3321-3323.

14. Nei, M. 1977. F-statistics and analysis of gene diversity in subdivided populations. Ann. Human Genet. 41, 225-233.

15. Parks, J. C. and C. R. Werth. 1993. A study of spatial features of clones in a population of bracken fern, Pteridium aquilinum (Dennstaedtiaceae). Am J. Bot. 80, 537-544.

16. Saitou, N. and M. Nei. 1987. The neighbor-joining method: A new method for reconstructing phylogenetic trees. $\mathrm{Mol}$. Biol. Evol. 4, 406-425.

17. Wright, S. 1965. The interpretation of population structure by $F$-statistics with special regard to systems of mating. Evolution 19, 395-420.

18. Yeh, F. C., R. C. Yang, and T. Boyle. 1999. POPGENE Version 1.31, Microsoft Windows-based Freeware for Population Genetic Analysis. University of Alberta, Alberta.

19. Zohary, D. and M. Hopf. 2000. Domestication of Plants in the Old World pp. 211, 3rd eds., Oxford University Press, New Headway.

\section{초록 : RAPD 마커에 의한 수집된 홍화자원에서 계통관계와 유전적 다양성}

성정숙 · 조규택 · 이기안 · 백형진 · 허만규 ${ }^{*}$

(농촌진흥청 농업유전자원센터, ${ }^{1}$ 동의대학교 분자생물학과)

홍화(Carthamus tinctorius L.)는 세계 여러 나라에 분포하고 있는 초본류이다. 이 종은 경제적으로 중요한데 홍 화는 약용, 적색소, 노랑 색소로 이용된다. RAPD 기법으로 홍화의 26 집단 간 유연관계와 유전적 다양성을 조사 하였다. 모든 집단에서 123 개 밴드를 얻었으며 시발체(primer) 당 평균 9.5 개 밴드를 나타내었다. 홍화의 유전적 다양도는 집단 내에 대부분 귀속되며 높은 집단 간 분화를 나타내었다. OPC18-01 밴드는 시리아 그룹에 특이 밴드였으며 다른 나라 집단에서는 발견되지 않았다. 이런 7개 특이 마크(SCAR)를 발견하였다. 비록 홍화의 분석 한 개체 수가 적고 각 나라의 대표성을 의미하지 않지만 본 연구 결과 지중해의 지역(모로코, 시리아, 터키)이 인도를 제외한 다른 지역보다 변이가 높았다. 단순히 RAPD만으로 단정하기 어렵지만 홍화의 기원 센터의 후보 군으로 지중해 연안으로 추정된다. 인도 역시 홍화의 2 차 센터의 후보군이다. RAPD 마커는 홍화의 자연 집단을 분류하는데 효과적이었다. 